\title{
Histopathology of Organs from Neonate Offspring Born to Female Rats Exposed to Sublethal Doses of Biological and Synthetic Insecticides
}

\author{
Histopatología de Órganos de Ratas Recién Nacidas Sometidas \\ a Dosis Subletales de Insecticidas Sintéticos y Biológicos
}

\begin{abstract}
Hilda Michelly Paiva dos Santos; Valéria Wanderley Teixeira; Álvaro Aguiar Coelho Teixeira; Rosimere da Silva; Ana Janaina Jeanine Martins Lemos; Clovis José Cavalcanti Lapa Neto \& Cintia Giselle Martins Ferreira
\end{abstract}

DOS SANTOS, P. H. M; TEIXEIRA, W. V.; TEIXEIRA, C. A. A; DA SILVA, R.; LEMOS, M. A. J. J.; NETO, L. C. C. J. \& FERREIRA, M. C. G. Histopathology of organs from neonate offspring born to female rats exposed to sublethal doses of biological and synthetic insecticides. Int. J. Morphol., 31(1):246-253, 2013.

SUMMARY: The current annual consumption of insecticides in agriculture in Brazil is over three million tons. The exposure happens through food that is contaminated with toxic waste and respiratory and dermal absorption. Biological control with Bacillus thuringiensis Berliner (Bt) has assumed increasing importance replacing the use of conventional insecticides. However, the tests used to justify approval for use and market release of Bt products, and the protocols used to assess the development of toxicity, are extremely superficial. In addition, more studies comparing effects between males and females and during pregnancy and lactation have not been conducted. Thus, the hypothesis tested in this study was if the administration of the XenTari ${ }^{\circledR}$ WG (Bacillus thuringiensis subsp. Aizawai) biological insecticide and Decis ${ }^{\circledR} 25 \mathrm{CE}$ (Deltamethrin) synthetic insecticide, at concentrations that do not cause clinical signs of maternal toxicity, could interfere in the histophysiology of the organs of neonate rats. Thirty-five pregnant albino rats, Rattus norvegicus albinus, were randomly distributed in seven groups: Group I received placebo (water); Groups II, III, and IV received 1.0, 10.0, and 20.0 $\mathrm{mg}$ of XenTari®/kg respectively; and Groups V, VI, and VII received 1.0, 2.0, and $4.0 \mathrm{mg}$ of Deltamethrin/kg, respectively. The results showed that the highest doses of insecticides reduced the number of neonates. No histopathological alterations were observed in the kidneys, however, lipidosis, diffuse mononuclear inflammatory cells, and sinusoids congestion were observed in the liver. Rats from groups IV and VII presented atresia in the ovaries. Neonates from Group IV showed congestion and hemosiderin deposition in the testicle's blood vessels, which is characteristic of a process of hemolysis. In conclusion, both insecticides presented similar effects on organs and number of neonates born to rats exposed to sub-lethal doses that did not cause clinical symptoms of maternal intoxication.

KEY WORDS: Bacillus thuringiensis; Synthetic insecticide; Rats; Histology; Histochemistry.

\section{INTRODUCTION}

Insecticides are among the most important risk factors for the health of workers and the environment because they are used in large scale by various productive sectors and more intensely in agriculture. The number of rural workers exposed to these insecticides is expressive in Brazil. Approximately $60 \%$ of this workforce is represented by women working in the production of diverse cultures such as grapes, acerola, and tomatoes, which contributes to increased exposure (Garcia \& Almeida, 1991). The exposures are, in general, associated to acute intoxication, chronic diseases, reproductive problems and environmental damage (Faria et al., 2007).
The pyrethroids, organophosphates, and carbamates are among the synthetic insecticides most currently used. These are lipophilic compounds widely used in agricultural pest control and in veterinary practices. The exposure to these products occurs through food contaminated with toxic waste, and respiratory and dermal absorption (Cantarutti, 2005). The risks of exposure to insecticides during manufacturing and application and depending on the product and healthcare follow up can often be fatal. Because of extreme persistence, some insecticides are found contaminating aquatic and terrestrial environments for many years (Andrade et al., 2002). These compounds can come in contact with food through 
direct application during production, transportation, or storing. Once in the body, these compounds can alter the physiology of the endocrine system through multiple mechanisms, in particularly the ability to mimicry hormones as the result of similarities in molecular structure (Schnorr et al., 2001).

Biological pest control has assumed increasing importance as an alternative to the use of chemical insecticides and results from the emphasis to reduce the use of insecticides. The bacterium Bacillus thuringiensis Berliner (Bt) is among the microorganisms used in biological control; the search for insecticide proteins and, consequently, the identification of their coding genes is promising (Crickmore et al., 1998; Bobrowski et al., 2003; High et al., 2004). These bacilli can be safely used against non-targeted organisms and do not present cumulative effects on the food chain (Kumar et al., 2000); they are considered environmentally safe by the World Health Organization (WHO). B. thuringiensis is a Grampositive bacteria characterized by the production of a parasporal crystal in the mother cell (during sporulation) which contains delta-endotoxins that are active against several orders of insects (Schnepf et al., 1998).

However, the tests used to justify approval for use and market release of Bt products, and the protocols used to assess the development of toxicity are extremely superficial. In addition, more studies comparing between males and females and during pregnancy and lactation have not been performed (Domingo, 2000; Janer et al., 2008). Studies conducted by Lemos et al., (2011) showed that the use of biological insecticide in the sublethal dose of $370 \mathrm{mg} / 100 \mathrm{gr}$ (Xentari ${ }^{\circledR}$ WG) produced qualitative and quantitative changes in the endometrium-blastocyst interaction in albino rats. These alterations were similar to the ones observed with the use of sublethal doses of $4 \mathrm{mg} / \mathrm{Kg}$ of the Deltamethrin (Decis ® 25CE) which compromises the implantation process in the uterus, and subsequently causes damage or death to the fetus. There are no studies evaluating the histopathological interference in neonates born to rats exposed to insecticides during the gestational period. Hence, the hypothesis that the administration of biological and synthetic insecticides at concentrations that do not cause clinical signs of maternal toxicity may interfere with the number of neonates and the histopathology of their kidneys, liver, lungs, and gonads was tested.

\section{MATERIAL AND METHOD}

The experiments were conducted at the Histology Laboratory in the Department of Animal Morphology and Physiology from the Federal Rural University of
Pernambuco (Brazil) and after approval by the Ethics Committee from this institution under number 23082.019868/2009. Thirty-five virgin albino rats, Rattus norvegicus albinus, from the Wistar strain, at 90 days of age and weighing $200 \pm 30 \mathrm{~g}$ were used in the study. The animals were kept in cages at $22{ }^{\circ} \mathrm{C}$ and artificial lighting with a 12:12 photoperiod (lights were on between 6 am and $6 \mathrm{pm}$ ); the animals received food and water ad libitum. Vaginal smears were collected for the determination of the estrous cycle. Animals with three regular estrous cycles were paired to mate and subsequently divided into the following groups: Group I receiving placebo (water); Groups II, III, and IV receiving 1.0, 10.0, and $20.0 \mathrm{mg} / \mathrm{kg}$ of XenTari®, respectively; and Groups V, VI, and VII receiving $1.0,2.0$, and $4.0 \mathrm{mg} / \mathrm{kg}$ of Deltamethrin, respectively. The animals were observed during pregnancy and neonates were sacrificed on the first day after birth. The insecticides were administered daily, immediately after the confirmation of copulation, through an oral probe and following the modified method of Shaban et al., (2003) for the biological insecticide and Andrade et al. for the synthetic. The rats were weighed daily to monitor and correct insecticide doses to be administered in order to maintain consistency throughout the experiment. The LD50 for oral administration of the studied pesticides are: $>5000$ $\mathrm{mg} / \mathrm{kg}$ of body weight for XenTari ${ }^{\circledR}$ WG (B. thuringiensis aizawai.) and > $1190 \mathrm{mg} / \mathrm{kg}$ for Decis ${ }^{\circledR} 25 \mathrm{CE}$ (Deltamethrin).

The morphological analysis of neonates included the observation and follow up of the pregnant rats over a period of 21 days, i.e. until birth, counting, weighting, and measuring neonates; measurements from head to the tip of the tail were taken with a caliper, and examinations to assess the presence of malformations in the head, torso, or limbs were performed. The neonates were euthanized; organs were removed, cleaved, fixed, and maintained in Boüin liquid for 48 hours. The organs were subsequently dehydrated in an ethanol series (increasing concentration), diaphanized in xylene, impregnated, and included by paraffin. The blocks were cut in a microtome and stained with Hematoxylin -Eosin (H.E.) and periodic acid-Schiff (PAS)

\section{RESULTS}

The macroscopic analysis showed no signs of malformations in the head, limbs, thorax, and abdomen. Abortions did not occur. Table I presents the neonates' averages for number, body length and weight. No significant statistical difference was observed in the averages of body 
DOS SANTOS, P. H. M; TEIXEIRA, W. V.; TEIXEIRA, C. A. A; DA SILVA, R.; LEMOS, M. A. J. J.; NETO, L. C. C. J. \& FERREIRA, M. C. G. Histopathology of organs from neonate offspring born to female rats exposed to sublethal doses of biological and synthetic insecticides. Int. J. Morphol., 31(1):246-253, 2013.

Table I. Average ( \pm standard deviation) of the number, body length and weight of neonates in the experimental groups.

\begin{tabular}{lccc}
\hline Groups & Number & Body length & Weight \\
\hline G I- & $12.00 \pm 1.58 \mathrm{a}$ & $6.17 \pm 0.28 \mathrm{a}$ & $6.14 \pm 0.41 \mathrm{a}$ \\
G II & $11.60 \pm 0.89 \mathrm{a}$ & $5.92 \pm 0.37 \mathrm{a}$ & $5.57 \pm 0.34 \mathrm{a}$ \\
G III & $8.60 \pm 1.67 \mathrm{ab}$ & $6.30 \pm 0.05 \mathrm{a}$ & $5.80 \pm 0.31 \mathrm{a}$ \\
G IV & $6.20 \pm 1.09 \mathrm{~b}$ & $6.16 \pm 0.69 \mathrm{a}$ & $5.97 \pm 0.96 \mathrm{a}$ \\
G V & $8.20 \pm 2.20 \mathrm{ab}$ & $6.15 \pm 0.95 \mathrm{a}$ & $6.19 \pm 0.56 \mathrm{a}$ \\
G VI & $7.80 \pm 1.48 \mathrm{ab}$ & $6.32 \pm 0.26 \mathrm{a}$ & $6.10 \pm 0.30 \mathrm{a}$ \\
G VII & $4.80 \pm 2.58 \mathrm{~b}$ & $6.52 \pm 0.35 \mathrm{a}$ & $6.31 \pm 0.84 \mathrm{a}$ \\
\hline Statistics1 Fr & $\mathbf{2 4 . 4 8 9 0 ^ { \mathbf { 0 0 0 4 } }}$ & $\mathbf{9 . 4 8 9}^{\mathbf{0 . 1 4 7 9}}$ & $\mathbf{6 . 6 0 6}^{\mathbf{0 . 3 5 8 9}}$ \\
\hline
\end{tabular}

length and weight, however, the number of neonates differed between the groups; the groups exposed to the highest doses of the biological and synthetic insecticides showed a significant reduction in number of neonates compared with the control group.

The liver of neonates from the control group presented, externally, a thin capsule composed of fibrous connective tissue, and a well-developed parenchyma showing a mesh of vascular veins with multiple calibers. The hepatocytes spread in a disorganized fashion around the lobular central vein edging the sinusoid capillaries (Fig. 1A). However, the presence of diffuse cellular vacuolization, characterizing hepatic lipidosis, was observed in the liver of neonates from Group II, III, and IV. This clinical picture was expressive in the liver of neonates whose mothers were exposed to the highest doses of the biological insecticide (Fig. 1B). A diffuse cellular vacuolization (lipidosis) and diffuse intense mononuclear inflammatory reaction were also observed in the group receiving the synthetic insecticide, with the predominance of the presence of lymphocytes in addition to perivascular polymorphic inflammatory reaction. Intravascular deposition of hemosiderin was observed in neonates from group VI (Fig. 1 C).

The kidneys of animals from the control group presented fibrous capsule, and well defined cortical and medullar regions (Fig. 1 D). Histopathological alterations were not observed in the kidneys of neonates from the groups exposed to XenTari ${ }^{\circledR} W G$ and Decis ${ }^{\circledR} 25 \mathrm{CE}$. The Bowman's capsule, well-differentiated capsular space, and well-developed glomeruli were observed. Extensive areas of connective tissue were observed in the medullar region (Figs. 1E - F).

The ovaries of the neonates from the control group were coated by a well-developed germinal epithelium consisting of cubic cells over a thin layer of dense connective tissue forming the tunica albuginea. Inside, the presence of oogonia cells in division, together with others showing atresia, was observed (Fig. 2A). This process is characterized by the halt of mitosis, separation of the cells from the basal lamina, and oocyte death. This atresia was more expressive in the neonates from the groups exposed to the highest doses of the biological (Group IV) and synthetic (Group VII) insecticides (Figs 2B - C) when compared to the control group (Fig. 2A).

The testicles of neonates from group I, II, and III were coated by a well-preserved germinal epithelium resting on a capsule of dense connective tissue, the tunica albuginea. The presence of numerous seminiferous tubules sheltered as hanks within a loose connective tissue was observed inside the testicles (Fig. 2D). In the tubules, numerous spermatogonia at various sizes were identified in the presence of Sertoli cells anchored to the basal lamina of the tubules with their apical tips facing the lumen. Several Leydig's cells were also identified between the tubules, and characterized by the presence of heavily stained and vacuolated cytoplasm. The presence of numerous blood vessels with characteristics of congestion and discreet hemosiderin deposition was observed in the tunica albuginea in the testicles from neonates whose mothers were exposed to the highest dosage of XenTari® (Fig. 2E). It was possible to note that the spermatogonia were vacuolated in the V, VI, and VII groups, which were exposed to Decis ${ }^{\circ}$, and thus, indicating a degenerative process (Fig. 2F).

\section{DISCUSSION}

The results showed that exposure to sublethal doses of biological and synthetic insecticides during pregnancy did not affect the weight of the adult female rats or the body 
DOS SANTOS, P. H. M; TEIXEIRA, W. V.; TEIXEIRA, C. A. A; DA SILVA, R.; LEMOS, M. A. J. J.; NETO, L. C. C. J. \& FERREIRA, M. C. G. Histopathology of organs from neonate offspring born to female rats exposed to sublethal doses of biological and synthetic insecticides. Int. J. Morphol., 31(1):246-253, 2013.
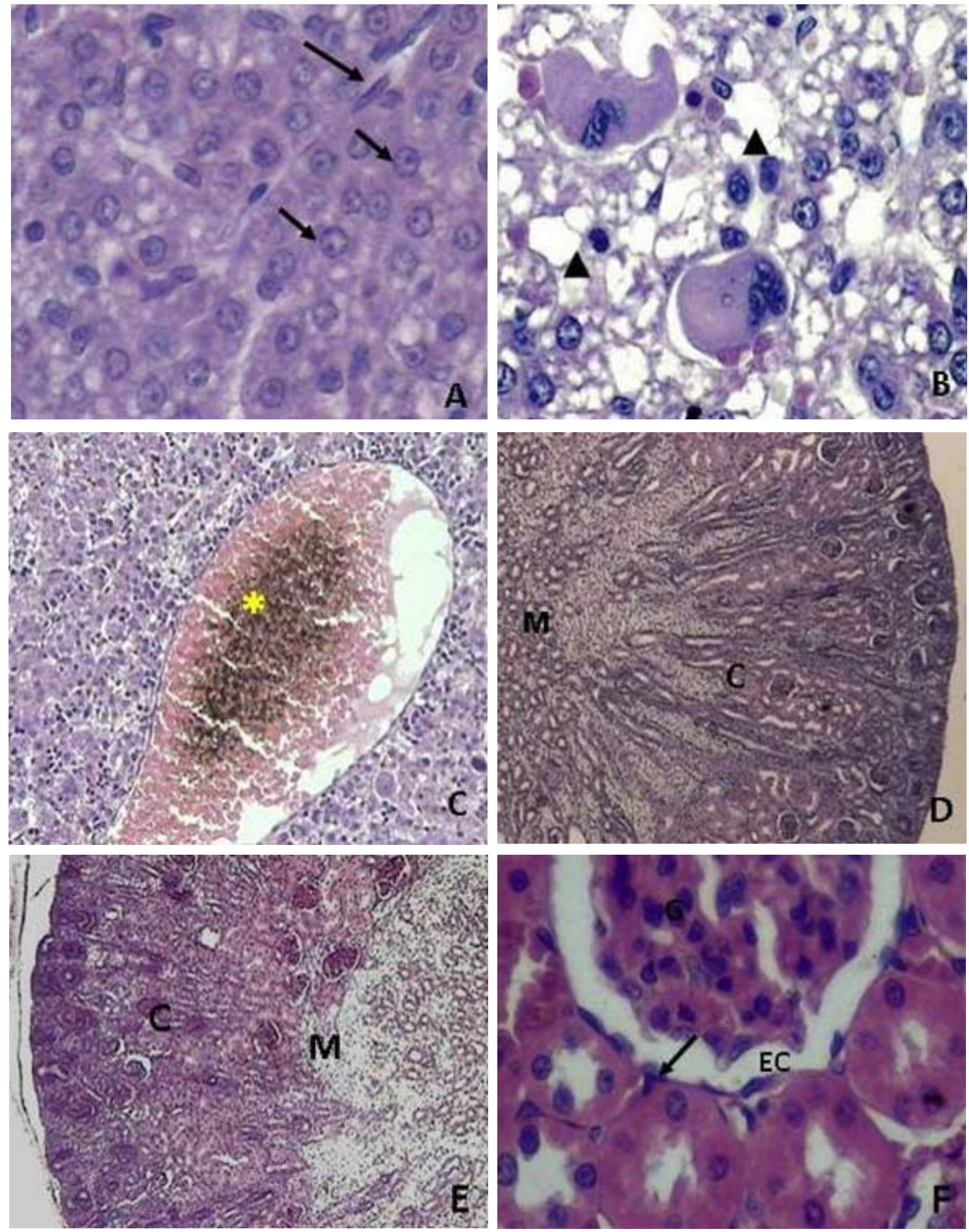

Fig. 1. A. Liver of a neonate from the control group. H.E. Staining, $\pm 428 X$. B. Liver of a neonate from Group IV. Severe lipidosis . H.E. Staining, $\pm 428 X$. C. Liver of a neonate from Group VI. Note deposition of hemosiderin. H.E. Staining, $\pm 428 X$. D. Kidney of a neonate from the control group. H.E. Staining, $\pm 42 X$. E. Kidney of a neonate from Group III. H.E. Staining, \pm $42 X$. F - Kidney of a neonate from the control group. H.E. Staining, $\pm 42 X$. Long arrow -capillary sinusoid; short arrow hepatocyte; arrowhead - lipidosis; C - Cortical Region; M - Medullar Region; * - hemosiderin. 

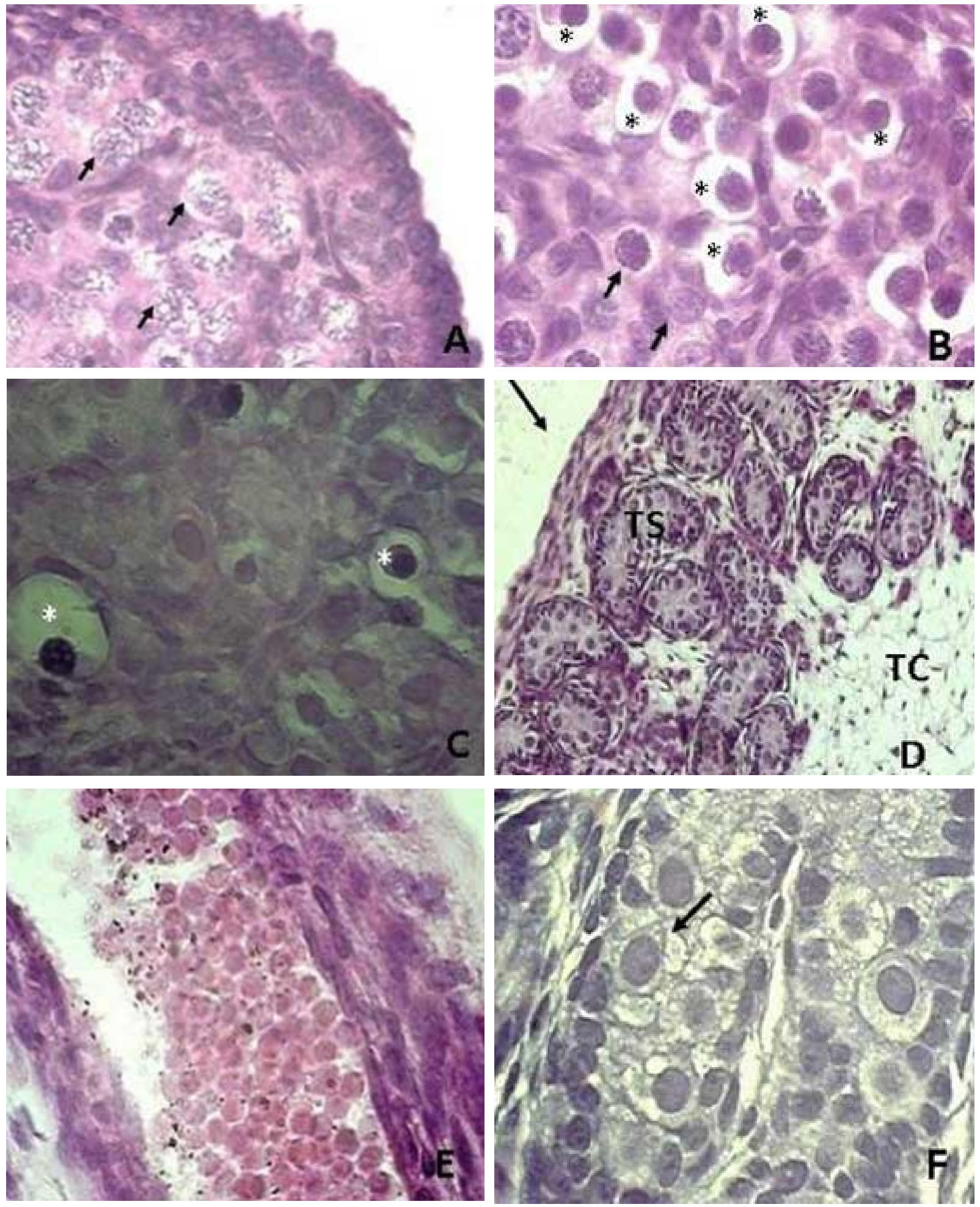

Fig. 2. A. Ovary of a neonate from the control group. H.E. Staining, $\pm 428 X$. B. Observe dividing cells and atresia in the ovaries of neonates from Group IV. H.E. Staining, $\pm 428 X$. C. follicular atresia (Group VI). H.E. Staining, $\pm 428 X$. D. Testicles of neonates from the control group. H.E. Staining, $\pm 107 X$. Observe blood vessel with deposit of hemosiderin in the testicles of neonates from Group IV. H.E. Staining, $\pm 428 X$. F. Seminiferous tubules with multiple espermatogonia showing vacuoles in the cytoplasm (Group VII). H.E. Staining, $\pm 428 X$. Short arrow - germinal epithelium; *- atresia; TS - seminiferous tubules; TC connective tissue; Long arrow - espermatogonia with degenerative process. 
DOS SANTOS, P. H. M; TEIXEIRA, W. V.; TEIXEIRA, C. A. A; DA SILVA, R.; LEMOS, M. A. J. J.; NETO, L. C. C. J. \& FERREIRA, M. C. G. Histopathology of organs from neonate offspring born to female rats exposed to sublethal doses of biological and synthetic insecticides. Int. J. Morphol., 31(1):246-253, 2013.

length of neonates. However, the number of neonates was significantly reduced in the group exposed to the highest dosage of both biological and synthetic insecticides. This reduction could be a result of a proinflammatory process in the uterine mucosa produced by $\mathrm{Bt}$ in the dosage of 20.0 $\mathrm{mg} / 100 \mathrm{~g}$. According to Moreno-Fierros et al., (2000), Bt Cry 1Ac protein toxins can cause systemic immune responses in various locations, such as the reproductive system, after intraperitoneal and intravaginal application of $100 \mu \mathrm{g}$. It has also been reported that this toxin (Cry1Ac) is a specific potent inducer of immune responses in the uterine mucosal (Vázquez-Padrón et al., 2000).

The hepatic histopathological analysis revealed a picture characteristic of lipidosis. This could be the result of the liver's role in processing all toxic substances in the body and possibly becoming debilitated when the level of toxins in the body is high. According to Varela-Rey et al., (2009), the presence of lipid vacuoles in the cytoplasm of hepatocytes can lead to complications such as cirrhosis, hepatic carcinoma, diabetes, hyperlipidemia, and hypertension. Sun et al. (2001) reported that Bt has the capacity to change the defense behavior of liver cells, induce oxidative stress, stimulate lipid peroxidation due to the formation of free radicals, and damage the cell membranes of hepatocytes in rats, and consequently leading to an inflammatory reaction. The dilatation of the lumen of sinusoids, infiltration of inflammatory cells, degeneration of hepatocytes, and increased levels of the LDH enzyme were evidenced in a study using deltamethrin in the dosage of $668 \mathrm{ppm}$ (1/10 of the LD50) via intraperitoneal (Fetoui et al., 2009). The data suggest that prenatal exposure to low doses of pyrethroids has the potential of producing lasting effects on the expression of cytochrome $\mathrm{P} 450$ involved in the metabolism of xenobiotics in the brain and liver of offspring (Johri et al., 2006).

The absence of histopathological alterations in the kidneys could be associated with the hepatic activity in the process of detoxification because the metabolism of neonates is faster compared to adult's metabolism. This process forces lipophilic substances, which easily pass through the placenta, to remain in the neonate's body for a shorter time than in the mothers' body (Kim et al., 2008; Mettler et al., 2008). Therefore, even with the observation of liver and gonads from neonates showing severe alterations, it seems that the hepatic activity prevented the toxin to spread to the kidneys.

The presence of the highest atresia in the ovarian follicles and mesenchyme in the ovaries of neonates whose mothers were exposed to the highest dosages of the biological insecticide could be the result from the effects of oxidative stress produced by the Bt formulation (Tsai et al., 2006).
According to Murdoch (1998) and Behrman et al., (2001), the oxidative stress induces apoptosis in ovarian cells and is associated with mechanisms involved in the regression of the corpus luteum and follicular atresia.

The deposition of hemosiderin in blood vessels present in the tunica albuginea, and vascular congestion featuring a picture of hemolysis, were observed in the testicles of neonates born to the mothers exposed to the highest dosage of XenTari ${ }^{\circledR}$. It is known that hemosiderin is a brown pigment, contains iron, and is usually contained in the macrophages of the reticuloendothelial system. If excessive iron is absorbed or released from red blood cells during hemolysis, the storage in macrophages increases and considerable quantities can be accumulated. The quantity, therefore, might be indicative of iron reserves or degradation of red blood cells depending on the circumstances that initiated the accumulation. Andrade et al., observed that adult male rats exposed to dosages of $4.0 \mathrm{mg} / \mathrm{kg}$ of Deltamethrin presented reduced weight of the testis, epididymis, and sperm production.

In conclusion, both biological and synthetic insecticide produced histopathological alterations characterized by inflammatory reactions and reduction in the number of offspring. Both insecticides acted similarly on the kidneys, liver, and gonads of neonates born to mothers exposed to sublethal doses, which did not cause clinical symptoms of maternal intoxication.

DOS SANTOS, P. H. M; TEIXEIRA, W. V.; TEIXEIRA, C. A. A; DA SILVA, R.; LEMOS, M. A. J. J.; NETO, L. C. C. J. \& FERREIRA, M. C. G. Histopatología de órganos de ratas recién nacidas ratas induzidas a dosis subletales de insecticidas sintéticos y biológicos. Int. J. Morphol., 31(1):246-253, 2013.

RESUMEN: El consumo anual actual de insecticidas en la agricultura en Brasil es más de tres millones de toneladas. Aproximadamente el $60 \%$ de los trabajadores rurales expuestos a los insecticidas son mujeres. La exposición ocurre a través de alimentos contaminados con desechos tóxicos y la absorción respiratoria y dérmica. El control biológico con Bacillus thuringiensis Berliner (Bt) ha adquirido una importancia creciente en la sustitución del uso de insecticidas convencionales. Sin embargo, las pruebas utilizadas para justificar la aprobación para el uso y la liberación del mercado de los productos $\mathrm{Bt}$, y los protocolos utilizados para evaluar el desarrollo de toxicidad, son muy superficiales. Además, no se han realizado estudios que que permitan comparar los efectos entre hombres y mujeres y durante el embarazo y la lactancia. Por lo tanto, la hipótesis planteada en este estudio fue si la administración del Grupo de Trabajo XenTari ${ }^{\circledR}$ (B. thuringiensis subsp. Aizawai) insecticida biológico y Decis ${ }^{\circledR} 25 \mathrm{CE}$ (deltametrina) insecticidas sintéticos, en concentraciones que no causan signos clínicos de toxicidad materna, podría interferir en la histofisiología 
de los órganos de las ratas recién nacidas. Treinta y cinco ratas albinas preñadas, Rattus norvegicus albino, fueron distribuidas aleatoriamente en siete grupos: Grupo I recibió un placebo (agua), los Grupos II, III y IV recibieron 1,0, 10,0 y 20,0 mg de XenTari ® / kg, respectivamente, y Grupos V, VI y VII recibieron 1,0, 2,0 y 4,0 mg de deltametrina / kg, respectivamente. Los resultados mostraron que las dosis más altas de insecticidas redujeron el número de neonatos. No se observaron alteraciones histopatológicas en los riñones, sin embargo, se observaron en el hígado, lipidosis, difusas células inflamatorias mononucleares, y la congestión de sinusoides. Las ratas de los grupos IV y VII presentaron atresia ovárica. Los recién nacidos de grupo IV mostraron congestión y depósito de hemosiderina en los vasos sanguíneos del testículo, lo cual es característico de un proceso de hemólisis. En conclusión, los insecticidas presentaron efectos similares en los órganos y en el número de recién nacidos de ratas expuestas a dosis sub-letales, que no causan síntomas clínicos de toxicidad materna.

PALABRAS CLAVE: Bacillus thuringiensis; Insecticida sintético; Ratas; Histología; Histoquímica.

\section{REFERENCES}

Andrade, A. J. M.; Araújo, S.; Santana, G. M.; Ohi, M. \& Dalsenter, P. R. Reproductive Effects of Deltamethrin on Male Offspring of Rats Exposed during Pregnancy and Lactation. Regulatory Toxicology and Phamacology. 36 (3):310-7, 2002.

Behrman, H. R.; Kodaman, P. H.; Preston, S. L. \& Gao, S. Oxidative stress and the ovary. J. Society Gynecology Investigation, 8:S40-2, 2001.

Bobrowski, V. L.; Fiuza, L.M.; Pasquali, G. \& BodaneseZanettini, M. H. Genes de Bacillus thuringiensis: uma estratégia para conferir resistência a insetos em plantas. Ciência Rural. 33(5): 843-50, 2003.

Cantarutti, T. F. P. Risco tóxico de resíduos de pesticidas em alimentos e toxicidade reprodutiva em ratos wistar. Universidade Federal do Paraná. 2005.

Crickmore, N.; Zeigler, D. R.; Feitelson, J.; Schnepf, E.; Van Rie, J.; Lereclus, D.; Baum, J. \& Dean, D. H. Revision of the nomenclature for the Bacillus thuringiensis pesticidal crystal proteins. Microbiology and molecular biology review, 62(3): 807-13, 1998.

Domingo, J. L. Health risks of GM foods: Many options but few data. Science, 288:1748-9, 2000.

Faria, N. M. X.; Fassa, A. C. G. \& Facchini, L. A. Intoxicação por agrotóxicos no Brasil: os sistemas oficiais de informação e desafios para realização de estudos epidemiológicos. Ciência Saúde Coletiva. 12(1):2538,2007 .

Fetoui, H.; Garoui, E. M. \& Zeghal, N. Lambda-cyhalothrininduced biochemical and histopathological changes in the liver of rats: Ameliorative effect of ascorbic acid. Exp. Toxic. Pathol., 61:189-96, 2009.

Garcia G. E. \& Almeida, W. Exposiçäo dos trabalhadores rurais aos agrotóxicos no Brasil / Rural workers exposure to pesticides in Brazil. Rev. Bras. de Saúde Ocupacional, 19(72):7-11, 1991.

High, S. M.; Cohen, M. B.; Shu, Q. Y. \& Altosaar, I. Achieving successful deployment of Bt rice. Trends in Plant Science, 9(6):286-92, 2004.

Janer, G.; Slob, W.; Hakkert, B. C.; Vermeire, T. \& Piersma, A. H. A retrospective analysis of developmental toxicity studies in rat and rabbit: What is the added value of the rabbit as an additional test species?. Regul. Toxicol. Pharmacol., 50:206-17, 2008.

Johri, A.; Yadav, S.; Singh, R. L.; Dhawan, A.; Ali, M. \& Parma, D. Long lasting effects of prenatal exposure to deltamethrin on cerebral and hepatic cytochrome P450s and behavioral activity in rat offspring. European J. of Pharmacology, 544(1):58-68, 2006.

Kim, K.B.; Anand, S.S.; Kim, H.J.; White, C.A. \& Bruckner, J.V. Toxicokinets and tissue distribuition of deltramethin in adul Sprague - dawley rats. Toxicological Scienc.1019(2):97-205, 2008.

Kumar, A.; Sra, K; Sangodkar, U.M.X. \& Sharma, V.P. Advances in the bio-control of mosquito vectors utilizing Bacillus sphaericus and B. thuringiensis var. israelensis. Proceedings of the National Academy of Sciences India, 70:1-20, 2000.

Lemos, A. J. J. M.; Wanderley-Teixeira, V.; Teixeira, A. A. C.; Silva, F. C. A.; Oliveira, J. V. \& Siqueira, H. A. A. Response of blastocyst-endometrium interactions in albino rats to sublethal doses of biological and synthetic insecticides. Food And Chemical Toxicology, 49:25412547, 2011.

Mettler, F. A.; Huda, W.; Yoshizumi, T.T. \& Maherh, M. Effective doses radiology and diagostuc nuclear medicine: A Catolog. Radiology, 248 (1):254-63, 2008. 
DOS SANTOS, P. H. M; TEIXEIRA, W. V.; TEIXEIRA, C. A. A; DA SILVA, R.; LEMOS, M. A. J. J.; NETO, L. C. C. J. \& FERREIRA, M. C. G. Histopathology of organs from neonate offspring born to female rats exposed to sublethal doses of biological and synthetic insecticides. Int. J. Morphol., 31(1):246-253, 2013.

Moreno-Fierros, L.; García, N.; Gutiérrez, R.; López-Revila, R. \& Vasqués-Padrón, R. Intranasal, rectal and intraperitoneal immunization with protoxin Cry 1Ac from Bacillus thuringiensis induces compartmentalized serum, intestinal, vaginal and pulmonary immune response in Balb/c mice. Microbies Infect., 2:885-90, 2000 .

Murdoch, W. J. Inhibition by oestradiol of oxidative stressinduced apoptosis in pig ovarian tissues. J. Reproduction and Fertility. 114:127-30, 1998.

Schnepf, E.; Crickmore, N.; Rie, J. V.; Lereclus, D.; Baum, J.; Feitelson, J.; Zeigler, D. R. \& Dean, D. H. Bacillus thuringiensis and its pesticidal crystal proteins. Microbiology and Molecular Biology Review, 62:775806, 1998.

Schnorr, T. M.; Lawson, C. C. \& Whelan, E.A. Spontaneous abortion, sex ratio and paternal occupational exposure to 2,3,7,8-tetrachlorodibenzop-dioxin. Environ. Health Perspect. 109(11):1127-32, 2001.

Shaban, N. Z.; Helmy, M. H.; El-Kersh, M. A. R. \& Mahmoud, B. F. Effects of Bacillus thuringiensis toxin on hepatic lipid peroxidation and free-radical scavengers in rats given alpha-tocopherol or acetylsalicylate. Comparative Biochemistry and Physiology, 135:405-14, 2003.

Sun, X.; Kimura, T.; Kobayashi, T.; Noriki, S.; Imamura, Y.; Fukuda, M. \& Yamaguchi, A. Viability of liver grafts from fasted donor rats: relationship to sinusoidal endothelial cell apoptosis. J. Hepatobiliary Pancreat Surg. 8:268-73, 2001.

Tsai, S. F.; Yang, C.; Liu, B. L.; Hwang, J. S. \& Ho, S. P. Role of oxidative stress in thuringiensin-induced pulmonary toxicity. Toxicologic Appl. Pharmacol., 216: 347-53, 2006.

Varela-Rey, M.; Embade, N.; Ariz, V.; Lu, S.C.; Mato, J.M. \& Martinez-Chantar, M.L. Non-acoholicsteatohepatitis and animal models: Understanding the human disease. Int. J. Biochemistry \& Cell Biology, 41: 969-76, 2009.

Vázquez-Padrón, R. I. V.; Fierros, L. M.; Bazán, L. N.; Gil, A. F. M.; De La Riva, G. A. \& Revilla, R. L. Characterization of the mucosal and systemic immune response induced by Cry $1 \mathrm{Ac}$ protein from Bacillus thuringiensis HD 73 in mice Immunogenicity of Cry1Ac. Brazilian J. Med. Biol. Research. 33(2):147-55, 2000.

\section{Correspondence to:}

Álvaro Aguiar Coelho Teixeira

Department of Animal Morphology and Physiology

Federal Rural University of Pernambuco

Dom Manoel de Medeiros street

s/n Dois Irmãos

Recife-PE-Brazil

CEP 52171-900

BRAZIL

E-mail: alvaro@dmfa.ufrpe.br

Received: 28-07-2012

Accepted: 14-12-2012 